\title{
Childhood Supratentorial Neoplasm
}

National Cancer Institute

\section{Source}

National Cancer Institute. Childhood Supratentorial Neoplasm. NCI Thesaurus. Code C5960.

A neoplasm that affects the supratentorial region of the brain and occurs during childhood. 